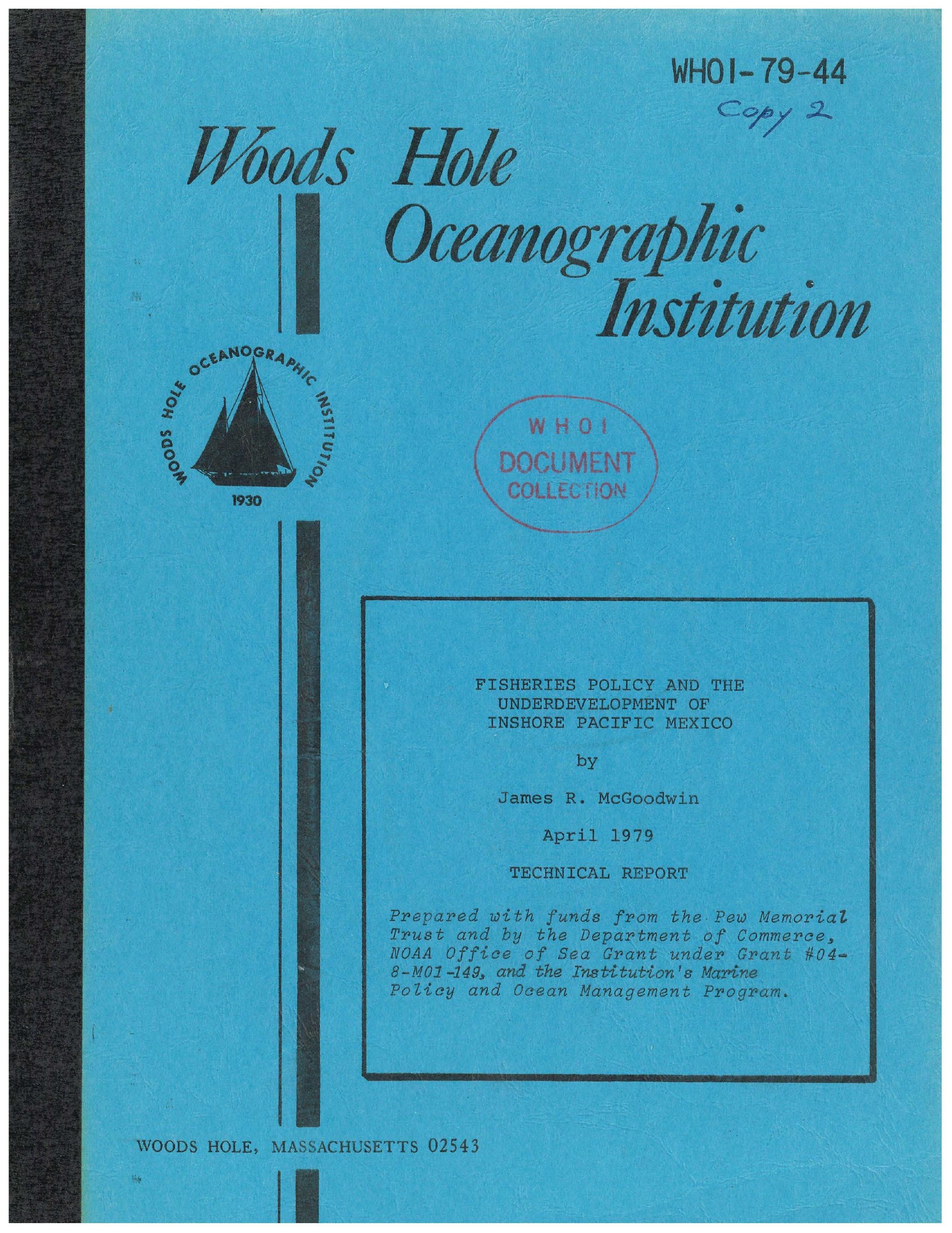


WHOI $-79-44$

\section{FISHERIES POLICY AND THE UNDERDEVELOPMENT \\ OF INSHORE PACIFIC MEXICO}
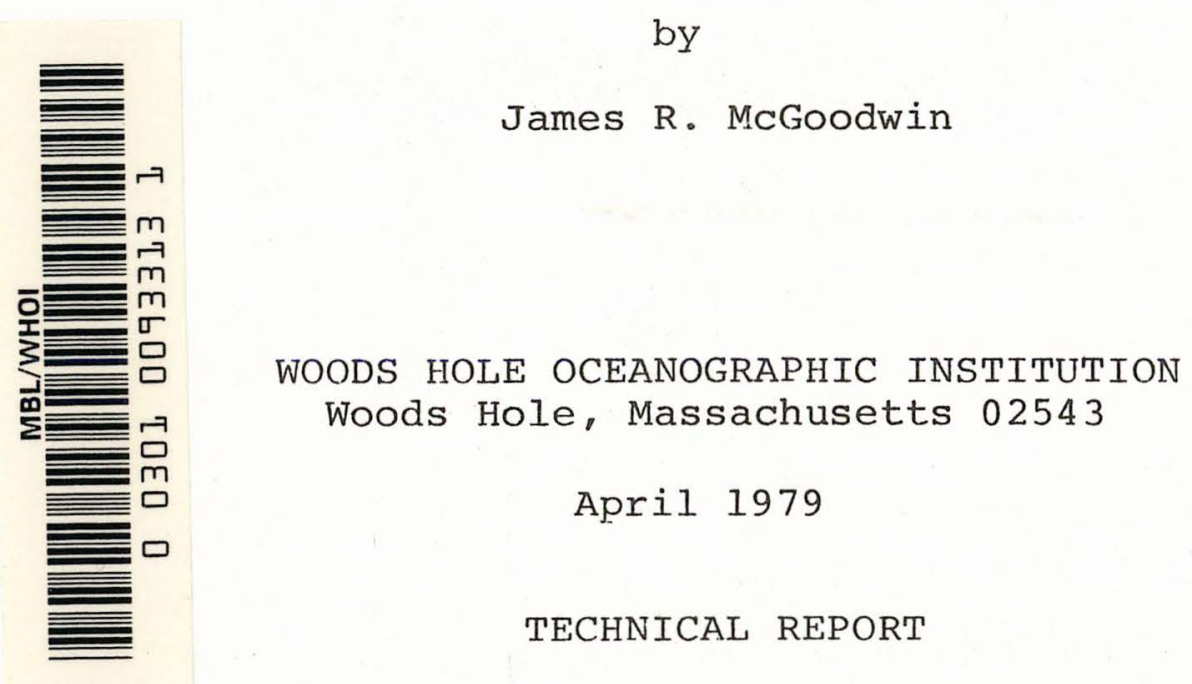

by

James R. McGoodwin

WOODS HOLE OCEANOGRAPHIC INSTITUTION Woods Hole, Massachusetts 02543

April 1979

TECHNICAL REPORT

Prepared with funds from the Pew Memorial Trust. and by the Department of Commerce, NOAA Office. of Sea Grant under Grant \#04-8-M01-149, and the Institution's Marine Policy and Ocean Management Program.

Reproduction in whole or in part is permitted for any purpose of the United States Government. This report should be cited as: Woods Hole oceanographic Institution Technical Report WHOI-79-44.

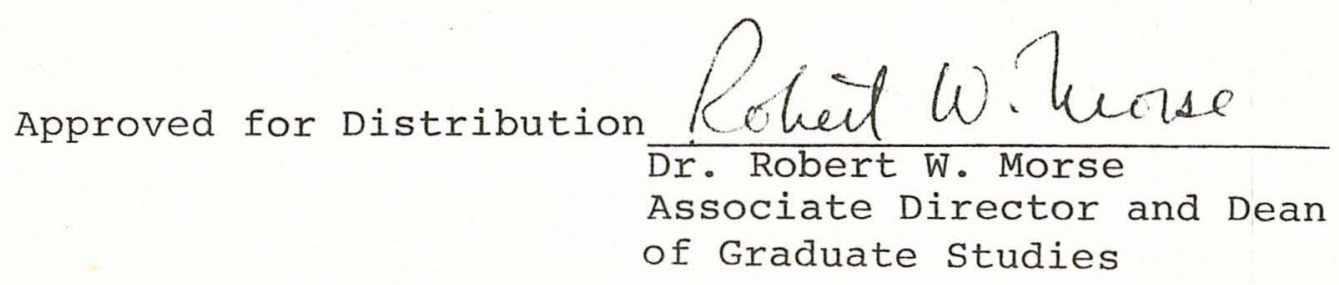


TABLE OF CONTENTS

Page

Abstract . . . . . . . . . . . . . . . . 3

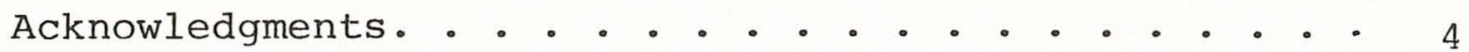

1. INTRODUCTION •. . . . . . . . . . . . 5

2. SOUTH SINALOA: A CASE IN POINT. • • • • • • 8

3. FISHERIES POLICY FOR PACIFIC MEXICO. • • • . 28

Appendix: Economy and Standards of Living in

South Sinaloa. . . . . . . . . . 34

References Cited . . . . . . . . . . . 39

Map 1: Major Inshore Pisheries of Pacific Mexico • 9

Table 1: Annual Shrimp Production of South Sinaloa's Major Inshore Fishing Cooperative, 1950-1970. 26 


\section{Abstract}

Development of shrimp-export industry brought about the underdevelopment of Pacific Mexico's inshore fisheries. The rural fishery of south Sinaloa provides a case in point, as well as a point of departure for considering fisheries development and management policy for similar fisheries in certain other less developed countries. 


\section{Acknowledgments}

The author wishes to thank the following colleagues who read earlier versions of this manuscript and offered helpful suggestions: Ann Martin, Susan B. Peterson, Leah J. Smith, H. Burr Steinbach, and Per Magnus Wijkman, Woods Hole Oceanographic Institution; John J. Poggie, Jr., and Richard B. Pollnac, University of Rhode Island and International Center for Marine Resource Development; John C. Cordel1, Stanford University; and Alexander Spoehr, University of Pittsburgh and East-West Center.

These early sources of support are also gratefully acknowledged: the E. D. Farmer International Fellowship Fund, Institute of Latin American Studies, The University of Texas, Austin, Texas, which supported my initial field work in Pacific Mexico from September, 1971 through October, 1972; and Council for Research and Creative Work, The Graduate School, University of Colorado, Boulder, Colorado, which supported a reconnaissance of Pacific Mexico's major inshore fisheries during summer, 1975. 
1. INTRODUCTION

Anticipating the conclusion of the Third United Nations Conference on the Law of the Sea (UNCLOS III), 80 coastal States have extended their jurisdictional claims over ocean economic resources to 200 miles from their shores. Most of these nations are enthusiastically promoting new maritime developments, and in the less developed countries (LDCs) the mood seems particularly bullish. Many of these nations, which are struggling with shortages of domestic food supplies and scarce capital for development, view their fisheries as a source of protein-rich foods, and a generator of considerable foreign exchange through international export trade.

However, before the LDCs surge ahead with the development of their fisheries, they might pause momentarily to consider the possible consequences of the various developmental strategies available to them, and to benefit from the experiences of other LDCs which have preceded them in fisheries development.

Pacific Mexico"s shrimp-fishing industry provides a particularly instructive case. The growth of the shrimp-export industry along Mexico's Pacific coast has 
been extraordinary, especially with regard to its generation of export income and the phenomenal quantities of capital it has accumulated. Sometimes, it seems that developmentalists, economists, and other social scientists have been so preoccupied with the nation's agrarian sector, that few have recognized that at $47.1 \%$ of total value crustaceans--and not petroleum, cotton, sugar, or any other primary commodity--are the nation's leading export item in terms of total value (Food and Agriculture Organization, 1972, and United Nations, 1972). Today Pacific Mexico boasts a huge, State-instituted, urbanbased, shrimp-export industry: seven trawler fleets with over 450 vessels; ten freezing, packing, and canning plants; two fisheries-research institutions; one shipyard; and two Mexican-owned importing corporations which are chartered in the United States and 1ocated in San Diego, California (Diario Oficial....1971). More than $94 \%$ of this industry's shrimp production is sent abroad: 29,000 metric tons of crustaceans in 1970, which brought nearly 62 million dollars (U.S.) in the international marketplace (Centro de Estudios Políticos, Económicos, y Sociales, 1973a and 1973b). 
But there is a poignant and relatively unknown aspect of the development of that industry. Its growth has also brought about the underdevelopment of the Pacific's rural-inshore fisheries, and the impoverishment of thousands of rural-coastal peoples living there. By and large, the plight of these peoples is relatively unknown outside of the regions they inhabit. Few social scientists have ventured into these uncomfortable regions, and fewer still have lived among their poor rural fishermen. This paper presents a case study of the underdevelopment of a rural-coastal fishery in a LDC, but the case may be applicable to the development policy of any LDC which has rich shrimp resources and an extensive, inshore, traditional fishing population. 
The major inshore fisheries of Pacific Mexico are shown on Map 1. These regions are the rearing grounds for Mexico's commercially important species of shrimp. In former times they also produced great quantities of other seafoods, particularly oysters and fish.

I focus on the rural fisheries in the municipio of Escuinapa, south Sinaloa, but the situation described for that region is more or less applicable to all of Pacific Mexico's rural-coastal fisheries. South Sinaloa is where today's shrimp-export industry had its beginnings, and in that region the social, economic, and political problems accompanying the growth of the industry have reached their point of greatest strain. Northward among the lagoons and estuaries of Sonora, for example, the rural population is relatively less dense, whereas southward-in the rural regions of the Gulf of Tehuantepec--the impact of the shrimp-export industry has been less severe. Nevertheless, living conditions in all of Pacific Mexico's rural-coastal regions are distressing (see Appendix: Contemporary standards of living 


\section{Map 1: Major Inshore Fisheries of Pacific Mexico}

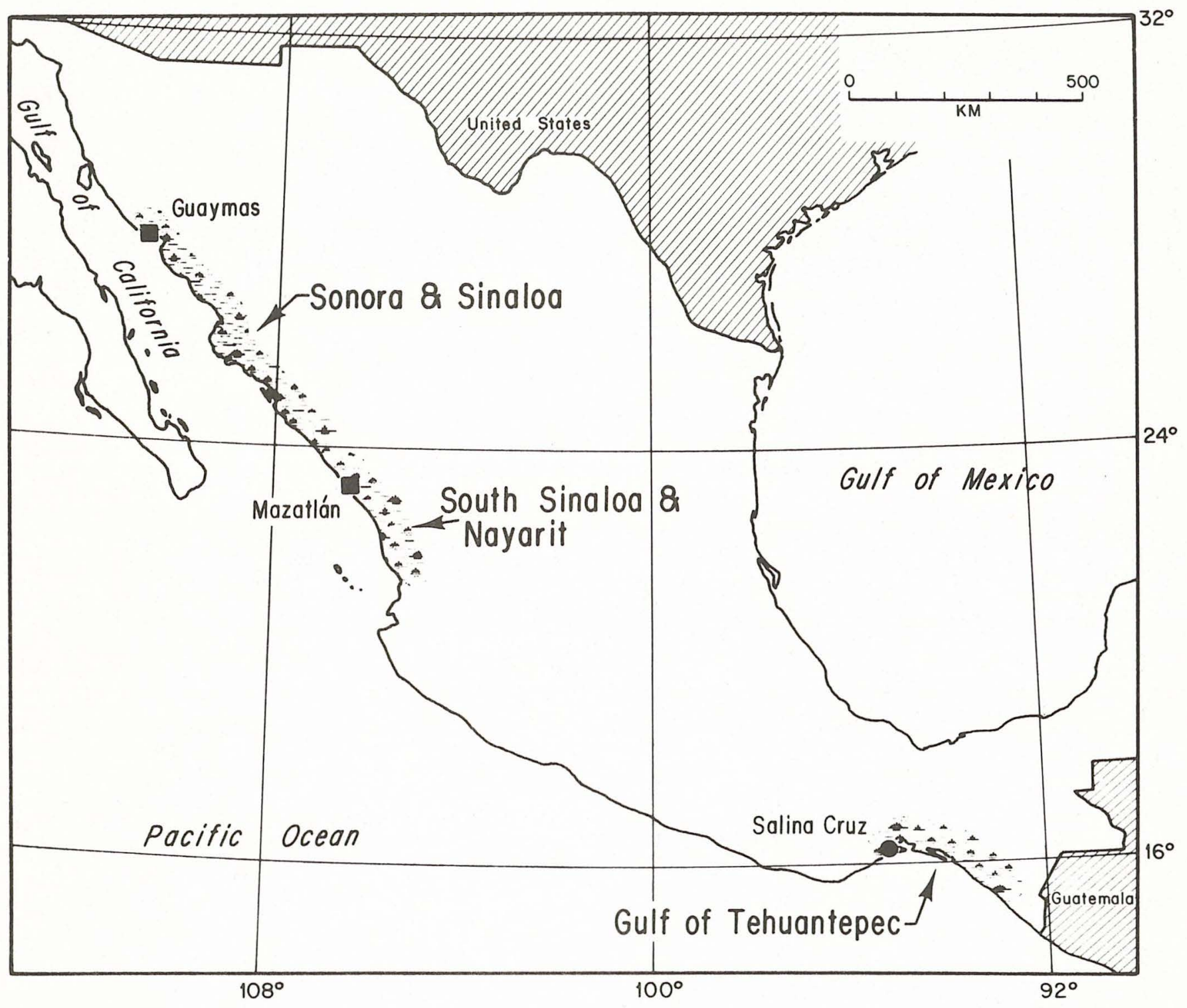


in south Sinaloa).

South Sinaloa's inshore fisheries were not always underdeveloped, nor were their human inhabitants as alienated from marine resources as they are today. Indeed, human beings have relied upon this region's rich coastal resources for at least 8,000 years--perhaps even longer--and evidence of a considerable and long-term maritime history is clearly apparent to even a casual observer (Hubbs and Roden, 1964).

The whole coastal region is interspersed with numerous shell mounds, some of them over three kilometers long and 200 meters wide, with peaks reaching 11 meters. Not far from Escuinapa, cabecera (head town) of the municipio by that same name, archeologists have recently discovered a particularly large shell mound--a proto-pyramid, perhaps--23 meters high, roughly quadrilateral in shape, and flat on top. Radiocarbon dating techniques indicate that this structure was built about 2,000 years ago, suggesting the existence of coastal chiefdoms, and perhaps even nascent states, which subsisted upon the region's seafoods sixteen centuries before the arrival 
of the Spanish conquerors (Scott et al., 1972).

Estimates of the pre-Colombian population vary and seem rather speculative, but various sources suggest that a relatively dense population inhabited the coastal plain at the time of the conquest. ${ }^{1}$ Apparently, the conquest era $a b-$ original population was part of the Mesoamerican culture tradition. They built platform mounds and ball courts on the higher ground fringing the coastal zone, decorated their pottery in the Mesoamerican style, grew corn, beans, and squash along the river courses, and harvested and traded quantities of seafoods from the estuaries and lagoons.

The conquest of south Sinaloa is noteworthy for

IThe cultural nature, and extent, of south Sinaloa's aboriginal population are discussed in scott et al., 1967-1972, Archeological Reconnaissances and Excavations in the Marismas Nacionales, Sinaloa and Nayarit, Mexico; Beals, 1932, "The Comparative Ethnology of Northern Mexico Before 1750"; Chevalier, 1970, Land and Society in Colonial Mexico: The Great Hacienda; Kelly and Winters, 1960, "A Revision of the Archeological Sequence in Sinaloa, Mexico,"; Spicer, 1969, "Northwest Mexico"; and Sauer and Brand, 1932, "Aztatlán". Fragmentary information about Sinaloa's conquest and its impact on the aboriginal population appears in Chevalier, 1970 (above); Bancroft, 1884, History of Mexico, Volume 1; Chipman, 1967, Nuño de Guzman and the Province of Panuco in New Spain: and Mecham, 1927, Francisco de Ibarra and Nueva Vizcaya. 
the extent to which it decimated the aboriginal population. The Indians were victims of diseases introduced by the Spaniards, and their ranks were further decimated by a number of factors which were either non-existent, or at least not as severe, in other parts of Conquest-era Mexico. First, they had the misfortune to be initially conquered by the genocidal Nuño de Guzmán. Soon thereafter, many were enslaved and taken to mines in the Sierra Madre Occidental, and to Cuba's distant sugar plantations. The scattered few who remained were pushed out of the region, displaced by the lords of the cattleraising haciendas which became prevalent in this region. Indeed, south Sinaloa was effectively depopulated of indigenous peoples by the 1750s, and today none inhabit the coastal zone. For nearly three centuries following its conquest, the region was almost empty of human inhabitants and its abundant marine resources were essentially unexploited. Then, in the early to middle 19th century, a trickle of new arrivals--mestizo immigrants from other parts of Mexico--settled coastal lands which became available following Mexico's 
independence from Spain. Still more immigrants arrived after the end of the French occupation. Many of these recognized the potential of the region's marine resources for subsistence and for commerce, and soon south Sinaloa's smoked oysters and salted shrimp were being carried by muleteers across the Sierra to Durango and southward toward Guadalajara and Mexico City.

The landmark event for these fisheries occurred in the early 1870 s when Chinese immigrants from MazatIán visited the region around Escuinapa, bought large quantities of shrimp and oysters, and began to sell these to buyers from southern California (U.S.), China, and Japan. In this manner south Sinaloa's rural fisheries made their debut in the international marketplace. 2

By the outbreak of the revolution in 1910, serious conflicts had begun to arise over south Sinaloa's marine resources. The Diaz administration had granted ${ }^{2}$ Probably the best account of sinaloa's colonial through revolutionary history is Gonzalez-Dávila, 1959, Diccionario Geografico, Historico, Biografico, y Estadistico del Estado de Sinaloa. 
exclusive fishing rights to a number of small companies and tried to limit subsistence activities by regional fishermen not employed by the companies. During the Revolution the brief Madero administration declared that subsistence fishing activities would be "free," and not subject to regulation. 3 Today subsistence fishermen are still identified by the term pescadores libres--only now that label has a pejorative, criminal connotation, especially among fishing-industry officials, who use the term with reference to fishermen who are not members of the State-sanctioned rural-fishing cooperatives. Theoretically subsistence fishing is still "free," but in actual practice it is greatly encumbered by various regulations which forbid shrimp harvesting for much of the year or which prohibit such fishing in territories exclusively reserved for the cooperatives.

By the end of the Revolution in the 1920s,

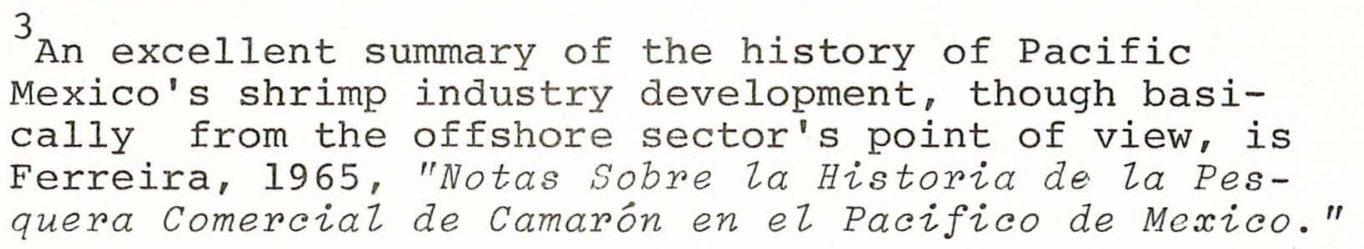


vessels from Japan and the United States were actively shrimp trawling along Mexico's Pacific coast. Mexico was powerless to prevent such incursions at that time, nor did it have sufficient capital with which to finance the construction of its own vessels. Instead it attempted to regulate and tax the foreigners fishing offshore, while developing its own shrimp-export industry in its inshore fisheries.

Offshore the Japanese eventually gained preeminence in the international shrimp market and drove their competitors from Mexico's Pacific coast by the middle 1930s. However, on the eve of the world war and fearing for the safety of their vessels so far from home, Japan abruptly withdrew its fleets from Pacific Mexico in 1939. Now at last Mexico had decisive control over all of its Pacific shrimp fisheries, and now it would begin to develop its own offshore fleets.

Mexico had already developed a system of Stateinstituted, inshore fishing cooperatives and central packing plants. Shortly after the Revolution the Pacific's lagoonal and estuarial regions were declared 
to be federal territories. Then, with passage of the Ley General de Cooperativas in 1933, the nation undertook development of the various "enterprises of State participation" which constitute its Pacific fishing industry today (Diario oficial de la Federación Mexicana, 1933). Producer's cooperatives were established in the rural areas, and a number of central packing plants to market the exports. The rural fishing cooperatives of south Sinaloa and the packing plant at Escuinapa were the first such organizations on this coast. Nearly all of the capital extended for the development of these cooperative enterprises went for the construction of the regional packing plants; development of the rural fishing cooperatives required little more than the concessioning of exclusive fishing territories and the recruitment of rural fishermen. The rural cooperatives required no more sophisticated technology than rudimentary and fairly inexpensive weirs constructed of mangrove posts and erected across tidal channels.

The rural cooperatives were inextricably bound to the regional packing plants by the terms of their 
charters. They were required to turn over all of their exportable production to these plants and to accept payment at whatever price levels the federal government established. Only in the conduct of their own internal affairs were they allowed to act as autonomous entities.

Initially this state of affairs was not a handicap to the rural cooperativistas. Marine resources were very plentiful, the new organizations accepted nearly all rural fishermen wishing to join, and existing price levels provided most fishermen with greatly increased cash incomes.

This was the era of the establishment of the nation's agrarian ejidos, and the rural fishing cooperatives were similarly hailed as important socioeconomic reforms. Proponents claimed that they would raise the standard of living of rural-coastal inhabitants and encourage wide participation in the fishing industry, and that the entire nation would benefit through production of vitally needed foodstuffs and the generation of export income. In retrospect, however, it seems that the generation of export income was the main reason they were founded, for the other 
reform-oriented goals have eroded.

As economic entities, the rural cooperatives were fairly successful from the time of their inception through the middle 1960s when Mexico's offshore shrimp-trawling industry would finally overshadow them. But long before that they had begun to suffer from serious social and political problems.

Probably the most serious early problem was corruption, or caciquismo (corrupt, political-economic bossism). During the Alemán administration, 1946-1952, caciquismo became widespread in the cooperatives, and it is still a problem in south Sinaloa. In many cases venal businessmen-politicians began to run the cooperatives for personal gain, relegating the cooperativistas to the status of mere shift laborers, while denying them participation in the cooperatives' internal affairs, a right guaranteed in the organizations' charters. During the Alemán administration analagous problems arose on the nation's ejidos, particularly those producing export items. That Mexico's rural campesinos have been 
relatively powerless to resist such corruption is a well documented phenomenon. 4

Other serious problems appeared. As the federal government periodically appropriated lands and redistributed these to impoverished campesinos-resettling many of these into sinaloa from other parts of the nation--south Sinaloa's rural-coastal population boomed,growing from around 8,000 persons in 1935, to nearly 31,000 in 1970 (Municipio de Escuinapa, 1971). As a result, competition for local marine resources intensified. Eventually the rural fishing cooperatives became entrenched economic entities, serving only a minority of the rural-coastal population, but from within they also suffered the effects of population growth, since their membership rights could be inherited by their descendants. Today most of south Sinaloa's cooperatives have more members 4Corruption in Pacific Mexico's rural fishing coopera-
tives is discussed in Beltrán, 1968, "Nuevas Leyes, Or-
ientación, y Financiamiento para la Pesca"; and Chávez,
1971, "Cooperativas Amenazadas." Caciquismo and offi-
cial corruption in Mexican collectives, particularly
those producing export commodities, are discussed in Paz
1972, The Other Mexico: Critique of the Pyramid; and Pi-
Sunyer, 1973, Change and Continuity in a Mexican Town. 
than they need, and these must distribute dwindling incomes among too many marginally productive members. By the early 1950s south Sinaloa's rural-coastal population had begun to suffer serious strains, and this situation was greatly aggravated when outboard motors and nylon nets were introduced into the fishery at that time. The use of outboard motors with large dugout canoes eased the transport of very large nets, while the nylon nets themselves, because they are nearly invisible underwater, proved disastrously effective in catching fish.

Because most of the region's shrimp and oyster production was being sent abroad, the fish which existed in great abundance in the estuaries and lagoons-snappers, snooks, drumfishes, mullets, and so forth-became the new mainstays of domestic consumption. However, the introduction of new technologies decimated the inshore fish stocks, reducing them to very low levels within only a few years. Rural fishermen speak of former times, before introduction of the motors and nets, when the surface waters of the lagoons sometimes appeared red from the shoals of snappers congregated there. Such is no longer seen. Continued fishing 
pressure prevents the recovery of these resources, and today's net fishermen rely upon secondary species, which are converted into fish meal, a highprotein dietary supplement for poultry and livestock. Why was the drastic overharvesting of these prodigious fish stocks not prevented by the federal government, since it is empowered to regulate these fisheries? One reason may be that the fish, however important as domestic foodstuffs, were the major predators upon the region's shrimp stocks.

The decline of south Sinaloa's rural-coastal fisheries was exacerbated by other factors. Natural catastrophes have played a part. In 1967, during the fall rainy season, a particularly severe flood buried the region's oyster beds under tons of silt, causing an almost total loss of that resource. Such floods have happened before in the region, at times with devastating consequences. Another flood in about 1,300 A.D. similarly destroyed the region's oyster beds, forcing the partial abandonment of the fishery for a number of years 
thereafter. ${ }^{5}$ Following the flood in 1967 , the federal government imposed a moratorium on oyster harvesting and attempted to re-establish the beds, but its efforts have been only partly successful. The much reduced oyster stocks have been subject to heavy pressure by rural campesinos, who illegally harvest them in order to provide food for their families, and they have been damaged by contaminants--chemical pesticides mostly--which are used in the region's agricultural sector.

Overshadowing all the foregoing disasters for south Sinaloa's rural fisheries has been the State's development of offshore trawling. The development of the trawling industry has brought about a parallel underdevelopment of the inshore fisheries, and to understand why it is necessary to comprehend the life cycle of Pacific Mexico's commercially important species of shrimp, all members of the Penaeid family.

5 Spicer, 1969 (note 1), observes that these innundations were important in the mythology and cosmology of the pre-Colombian coastal peoples. Scott, et al., 1967-1972 (note 1) discusses the impact of the unusually severe flood of cir. 1,3000 A.D. upon south Sinaloa's aboriginal population. 
In simplest terms, the shrimp are first hatched from fertilized eggs in the open sea, and then, while microscopically small larvae, they migrate up coastal estuaries and into briny lagoons. In those delicate environments they spend some months, growing to what would be recognizable as subadult shrimps. Finally they migrate back to the sea, reach their maximal size, and eventually spawn, thus completing their life cycle. ${ }^{6}$ Their seaward migration is particularly intense during the fall rainy season, when the influx of fresh water greatly reduces the salinity of the lagoons, and it is this movement which inshore fishermen have relied upon for thousands of years.

From the perspective of Pacific Mexico's offshore, shrimp-exporting sector and the marine biologists and fisheries managers who advise them, harvesting shrimp while they inhabit the inshore waters is regarded as poor practice. Inshore harvesting takes the shrimp out

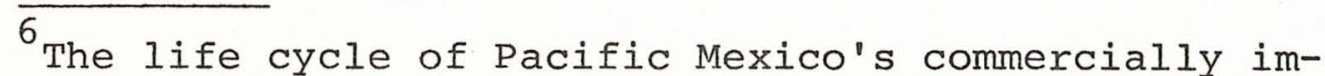
portant shrimp species, the influence of seasonal tide and rainfall cycles upon their numbers, and various fisheries-management implications--with special reference to the shrimp fisheries of south Sinaloa--are explained in Mendoza von Borstel, 1972, "Efectos de la Marea Sobre la Producción Camaronera en Lagunas Litorales." 
of the ecosystem before they have a chance to spawn, which threatens the ability of the resource to recover rapidly; by taking the shrimp before they reach adult size, the ecosystem's maximum potential shrimp biomass is not produced; the larger shrimp caught offshore bring higher prices per unit of weight in the international marketplace; harvesting shrimp with capital-intensive mechanized trawlers is less costly and far more productive than the lowyield and labor-intensive methods employed by inshore fishermen. 7

Thus, as Mexico's fisheries-development policy for its Pacific coast has emphasized the development of shrimp-export trade in this century, it has progressively curtailed the inshore shrimp harvest, dissociating the rural population from a resource which had been central to subsistence and commerce for

\footnotetext{
${ }^{7}$ Fisheries management issues such as these are discussed in Arnold and Bromley, 1970, "Social Goals, Problem Perception and Public Intervention: The Fishery"; Gales, Buss, and Bledsoe, 1977, "Simulation Concepts for Fishery Systems"; Gulland, 1969, Manual of Methods for Fish Stock Assessment: Fish Population Analysis; Lackey, 1975, "Fisheries and Ecological Models in Fisheries Resource Management"; and Schaaf, "Fish Population Models: Potential and Actual Links to Ecological Models." Contemporary fisheries management issues and events are reported in the monthly newsletter, Marine Fish Management.
} 
millennia. Today the government discourages the activities of subsistence-oriented pescadores libres, and permits south Sinaloa's rural cooperatives to harvest shrimp for only 10 to 12 weeks per year, whereas the voracious offshore trawlers are allowed 35 to 40 weeks of production annually. In Table 1 , the dramatic decrease in production of south Sinaloa's major inshore fishing cooperative--Sociedad Cooperativa General Lázaro Cárdenas--is charted over two decades: 1950-1970.

Other factors are indicative of the stressful quality of life in this rural-coastal zone. Ongoing conflicts among landowners, landless campesinos, and ejidatarios, for example, occasionally prompt group actions and violence similar to the highly publicized incidents which occurred in northern Sinaloa around the time of the last presidential succession. Severe conflicts also exist over rights to regional marine resources. Campesinos in the rural settlements sometimes shoot at the cooperatives' trucks--especially at night--as the vehicles pass through the countryside on their journeys between the lagoonal weirs and the packing plant. Campesinos engaged in subsistence 
TABLE 1

ANNUAL SHRIMP PRODUCTION OF SOUTH SINALOA'S MAJOR INSHORE FISHING COOPERATIVE, 1950-1970

\begin{tabular}{|c|c|c|}
\hline & Production & (metric tons) \\
\hline & 1950 & 1,900 \\
\hline & 1951 & 1,500 \\
\hline & 1952 & 2,400 \\
\hline & 1953 & 1,300 \\
\hline & 1954 & 2,300 \\
\hline & 1955 & 800 \\
\hline & $1956 *$ & 0 \\
\hline & 1957 & 450 \\
\hline & 1958 & 1,700 \\
\hline & 1959 & 1,000 \\
\hline & 1960 & 600 \\
\hline & 1961 & 900 \\
\hline & 1962 & 500 \\
\hline & $1963 *$ & 0 \\
\hline & 1964 & 400 \\
\hline & $1965 *$ & 0 \\
\hline & 1966 & 400 \\
\hline & 1967 & 500 \\
\hline & 1968 & 750 \\
\hline & 1969 & 600 \\
\hline & 1970 & 400 \\
\hline $\begin{array}{l}\text { *The } \\
\text { produc }\end{array}$ & $\begin{array}{l}\text { Federal government imposed a mor } \\
\text { ction in these years. }\end{array}$ & ratorium on \\
\hline
\end{tabular}


fishing are sometimes arrested by soldiers from the Infanteria Marina (the Navy's infantry), who are deployed in the fisheries during the fall shrimp harvest to enforce the cooperative's exclusive rights. Such enforcement measures have been unsuccessful, however, because of the pescadores libres' dispersion in the labyrinthian systems of estuaries and lagoons. A few large-scale shrimp contrabanders also seem to operate with relative impunity, perhaps buying their security.

South Sinaloa's rural fishermen are not ignorant of the events which have marginalized their traditional way of life. Often, in the context of discussions concerning the development of offshore trawling, they exclaim, "Camarón que duerme se la Zleva la marea" ("A shrimp that sleeps is taken by the tide"). The statement is an ironic, self-conscious acknowledgment of their sociopolitical dormancy, as well as inability to stem the tide of events which impoverished them. 


\section{FISHERIES POLICY FOR PACIFIC MEXICO}

It would be glib to conclude that the negative consequences of developing Pacific Mexico's shrimp-export industry could have been easily avoided. Hindsight is always clearer than foresight. When today's shrimp-export industry was first organized, the nation was badly in need of capital to finance its reconstruction, and, at least initially, the inshore fishing cooperatives did elevate the standard of living in the ruralcoastal areas. In 1933 the post-Revolutionary leaders could not have foreseen the great population growth to come, and given the nation's preoccupation with its agricultural sector at that time, and lack of interest in the cultural traditions of its inshore fishermen, these reformers should not be blamed for emphasizing the developmert of shrimp exports.

Mexico is now experiencing acute and widespread food shortages, rising infant mortality rates, and an exodus of its rural poor to its crowded cities and 
to the United States. ${ }^{8}$ Nevertheless, the federal government continues to announce further developments of its shrimp-export industry, despite ample evidence that the industry has already reached the limits of its growth (Wadsworth, 1973). Shrimp stocks have been declining for a number of years. Some industry entrepeneurs question the evidence, pointing out steady production increases over the past decade, but the industry's own fisheries biologists counter that such increases only reflect the annual addition of new trawlers to the fleets. Various methods for increasing shrimp stocks are still being tried; the most important involves

${ }^{8}$ Dr. Adolfo Chávez, Director of Mexico's Instituto Nacional de la Nutrición, says the following about economically depressed regions of rural Mexico such as south Sinaloa: "... we see infant mortality rising again. In some really depressed rural communities, few children born since 1974 have survived. We have what we call 'generational holes'" (Chávez, 1978: 3). Relationships between development of food-export trade and food shortages, rising infant mortality, and problems of socio-economic inequity which result--both in Mexico and in Latin America in general--are discussed in Lappé and Collins, 1977, Food First: Beyond the Myth of Scarcity, and Allsopp and Palacio, 1977," Reflections on Interciencia Marine Science Symposium." 
dredging projects which would facilitate the shrimp migrations between offshore and inshore waters, but these do not promise to make a significant difference over the long run (Mendoza von Borstel, 1972). Furthermore, since the industry exports nearly all of its production, its dependency upon the international market often places it in a precarious economic position. In 1971, for example, the United States' unilateral imposition of a $10 \%$ surcharge on import tariffs precipitated an economic crisis having painful ramifications throughout Mexico's shrimp industry. President Echeverría responded by courting other foreign buyers for Mexican shrimp, particularly the Japanese, promising he would "weaken the embrace of the North," but such actions were futile (T'échnica Pesquera, 1972: 8-9). The United States is still the purchaser of most of Mexico's shrimp exports, and the industry is still highly vulnerable to the vagaries of the international marketplace.

The industry's dependency upon the international market has also caused it to engage in market behavior which seems indefensible for a nation experiencing food 
shortages. In spring, 1978, for example, stories appeared in the nation's press about the destruction of large quantities of seafoods in order to drive up their price in the international market.

In the same period domestic food supplies were reported scarcer than ever. Those resources might instead have been distributed to ultimate consumers in food-deficient regions.

Mexico needs to seriously reconsider its policies for the management and development of its Pacific-coastal fisheries. It should stress revitalization of the inshore fisheries, encourage the resurgence of inshore fish stocks, and relax its restrictions upon individualistic subsistence fishermen and small-scale regional commerce. Positive steps should be taken to invigorate the nation's domestic seafood markets.

Such a change of policy would not be as radical as it first seems. Indeed, it may come about naturally as increased exports of petroleum from the Campeche Banks will appreciate the peso, thus reducing the relative profitability of shrimp exports. Perhaps then the nation will not have to rely as heavily as it has in the 
past upon the export of an important food commodity. Few LDCs are fortunate enough to have huge undeveloped reserves of energy resources, but they may learn much from the development of Mexico's shrimpexport industry. The Philippines, for example, has both rich shrimp resources and a large, traditional, rural-coastal fishing population, and that nation is now actively developing its fisheries. Having secured a 200-mile, offshore economic zone, the Philippines-like other coastal LDCs--is being lured by the export income which certain seafoods promise. Unfortunately, many LDCs ignore the poverty of their rural-coastal regions, viewing that and the development of their fisheries as distinct, or unrelated, problems. Here the work of anthropologists, ethnohistorians, rural sociologists, and economists could greatly inform the course of these nation's future fisheries' development. ${ }^{9}$ Anthropological studies dealing with the marginalization of traditional fishermen by marine-exports development include Cordell, 1973, "Modernization and Marginality," and 1978, "Swamp Dwellers of Bahia;" Firth, 1965, Malay Fishermen: Their Peasant Economy; Fraser, 1966, Fishermen of South Thailand; and Norbeck, 1954, Takashima: A Japanese Fishing Vilzage. Good introductions to fisheries management and development issues in the less developed countries appear in Koers, 1973, International Regulation of Marine Fisheries, and Rothschild, ed., 1972, World Fisheries Policy: Multidisciplinary Views. Broader political, economic, legal, and philosophical issues concerning rights to fisheries' resources are discussed in Christy, 1971, "Fisheries: Common Property, Open Access, and the Common Heritage." 
Fishing is a small part of the GNP in most nations. Even in Japan, a nation well known for its extensive fisheries and fishing traditions, the value of agricultural output exceeds that of fishing by 50 times (Nishimura, 1973: 3). As a result of its relatively small role in most nations, the fisheries is often not well understood as a socio-economic phenomenon. This may lead national economic planners to lump various forms of fishing under one rubric, so they fail to distinguish crucial differences between subsistence versus commercial fishing, or inshore versus offshore fishing. Moreover, many nations may not be sufficiently aware--because they lack the appropriate information--that increased income from fisheries' exports may, in some cases, be more than offset by the consequent social and economic costs in their ruralcoastal zones.

Fisheries' development-and-management policy is an extremely complex matter, requiring the consideration of sociocultural, political, economic, and biological phenomena. If the issues surrounding the development of fisheries in the LDCs are to be adequately addressed, the concerted efforts of government leaders, scientists, fishery managers, and fishermen will be required. 


\section{Appendix}

Economy and Standards of

Living in South Sinaloa

Over 30,000 persons now inhabit the approximately 300 square kilometers of lowlands in the municipio of Escuinapa along south Sinaloa's coastal plain. Slightly more than half of these occupy the head town, the rest live in 27 rural settlements ranging in size from about 70 to 2,500 persons (Municipio de Escuinapa, 1971). Fewer than 600 people--on1y $2 \%$ of the municipio's total population--are members of the region's rural fishing cooperatives or find work in its packing plant. The region's inshore cooperatives annually produce around 700 metric tons of shrimp, an insignificant quantity of miscellaneous fish, and no oysters. That production nets the cooperativistas annual individual incomes of slightly under $\$ 700.00$ (U.S.). Furthermore, 98 to $100 \%$ of that shrimp production is exported to the United States (Centro de Estudios Politicos Económicos y Sociales, 1973b). Hypothetically, if that same low level of shrimp production were distributed evenly throughout the municipio, it would annually provide every man, woman, and child with roughly 23 kilograms (over 50 pounds) of that protein-rich food. 
By any of the usual indicators, the municipio of Escuinapa can be classified as underdeveloped, its human population as impoverished. ${ }^{10}$ Average personal incomes among the region's household heads are less than $\$ 400.00$ (U.S.) per year. JornaZeros (day-wage laborers in agriculture) earn only about $\$ 2.50$ (U.S.) per day when employed, and the overwhelming majority of them are wage dependent, regardless of whether or not they have use of ejido lands. Furthermore, most wage-labor work is shortterm and seasonal, and usually there are more willing workers than jobs available at any given time.

Only $0.3 \%$ of the municipio's total population is professiona11y or technica11y trained, and in the rura1 settlements less than two years of primary school is the mean educational level. Housing standards are low. In the head town and the older rural settlements, there is housing of the "permanent-construction" type, 10

The "usual indicators" of underdevelopment implied here are those taken as indicative in United Nations, 1971, Economic Survey of Latin America, 2970.

${ }^{11}$ Quantitative data in this paragraph, as well as data appearing in the remainder of this sub-section (i.e. CONTEMPORARY STANDARDS OF LIVING IN SOUTH SINALOA) is from Casas Perez and Rodriquez Salgado, 1967, "Estudio para el Financiamiento Agropecuario en la Zona Sur de Sinaloa"; Centro de Estudios Políticos Economicos y Sociales, 1973a and 1973b; and Municipio de Escuinapa, 1971. The more qualitative information appearing in this subsection was noted by the author in the field, 1971-1978. 
but otherwise most dwellings are crowded, squalid, and barren within, lacking sanitary facilities and running water. Conditions are similar or even worse in the rural settlements, where many houses are constructed of vegetal materials. Throughout the municipio fresh drinking water is always in short supply, and the entire population must either buy purified water from commercial vendors, or take its chances with the region's brackish, often polluted shallow wells.

Health and nutritional levels are extremely low. Infant mortality rates are rising for the first time in decades. Various chronic diseases--infections, amebiasis, and hepatitis--are endemic and every year a number of cases of polio, tuberculosis, and rabies are reported.

Regional food supplies vary considerably throughout the year. Summer, for example, is a desperate season for most of the population; there are no significant agricultural harvests and fishing activity reaches its lowest ebb. Much of the population--rural and urban--suffers from sporadic food shortages, and nutritional disease is widespread throughout the region.

Only $20 \%$ of the municipio's surface area is suitable for cultivation; the rest is made up of marginal lands: brushy, rocky, and dry highlands, for example, or lowland beaches, salt pans, and marshes. 
Over $63 \%$ of the total surface area is privately owned, and most of the owners are absentees who live in distant urban centers, especially Culiacán, Guadalajara, and Mexico City. On1y $30 \%$ of the region's lands belong to the municipio's eleven ejidos, and many of these are so brushy, salty, and subject to inundation that they have little economic value, serving merely as house sites in many cases. A common expression used by many of the region's campesinos underscores the inadequacy of their lands; "Somos muy salados," many of them say, which literally translates, "We are very salted," but the expression is a double entendre, since "salado" is also slang meaning "unlucky."

Other attributes of the lowland environment compound the miseries of its human inhabitants. The climate is hot and humid most of the year, and the region's marshes produce hordes of biting insects, particularly mosquitos and jejenes--a tiny gnat having a vicious bite. These insects cause great discomfort and contribute to a high incidence of skin diseases in the region.

Technological levels are also indicative of the region's underdevelopment. In agriculture the use of human and animal labor predominates over that of machines. More than $90 \%$ of the arable land is devoted to the production of two low-yield traditional crops, corn and beans. More than $80 \%$ of the region's cattle are unproductive criollo types. Recently there has been some development 
of cash crops, particularly mangos, by a few fortunate investors having adequate supplies of starting capital, and sufficient resources to endure an initial period of no production. Technological items employed in fishing are rudimentary, and all forms of fishing are labor intensive. The fishermen use dugout canoes, home-made cast nets, and handlines with hooks and sinkers. The cooperatives use wooden weirs, large nets, and a few boats equipped with outboard motors, but other-wise lack important technological items--refrigeration, for example--which are important in modern commercial fishing. 


\section{References Cited}

Allsopp, W. H. L., and Francisco J. Palacio

1977 "Reflections on Interciencia Marine Science Symposium,"-Interciencia 2 (May).

Arnold, Victor L., and Daniel W. Bromley

1970 "Social Goals, Problem Perception, and Public Intervention: The Fishery," San Diego Law Review 7 (September).

Bancroft, Herbert $\mathrm{H}$.

1884 History of Mexico, Volume 1 (San Francisco).

Beals, Ralph L.

1932 "The Comparative Ethnology of Northern Mexico Before 1750," Ibero Americana (monograph) 2.

Casas Pérez, Manuel, and Gabriel Rodriquez Salgado

1967 "Estudio para el Financiamiento Agropecuario en la Zona Sur de Sinaloa," (Mexico, D. F.: Banco Agropecuario).

Centro de Estudios Políticos Económicos y Sociales (annual reports)

1973a "Sintesis Estatal," 1968-1973, Centro de Estudios Políticos Económicos y Sociales (Culiacán, Sinaloa).

$1973 \mathrm{~b}$ "Jornades de Información y Estudio para la Programmación del Desarollo de Sinaloa," 1968-1973, Centro de Estudios Políticos Económicos y Sociales (Culiacán, Sinaloa).

Chávez, Adolfo

1978 Cited by editors, Behaviar Today (March 20). 
Chávez, José

1971 "Cooperativas Amenazadas," Gaceta Cooperativa (May).

Chevalier, Francois

1967 "Ejido y Estabilidad en Mexico," America Indigena 17 (April).

1970 Land and Society in Colonial Mexico: The Great Hacienda, (Berkeley: The University of California Press).

Chipman, Donald

1967 Nuño de Guzmán and the Province of Panuco in New Spain, 1518-1533, (Glendale).

Christy, Francis T., Jr.

1971 "Fisheries: Common Property, Open Access, and the Common Heritage," In Elisabeth Mann Borgese, ed., Pacem in Maribus, (New York: Dodd, Mead, and Company).

Cordell, John C.

1973 "Modernization and Marginality," Oceanus 5 (17) 。

1978 "Swamp Dwellers of Bahia," Natural History (July).

Diario oficial de la Federación Mexicana

1933 "Ley General de Cooperativas," Diario Oficial de la Federación Mexicana (México, D. F.).

1971 "Decreto por el que se Autoriza la Creación de una Empresa de Participación Estatal que se Denomirá Productos Pesqueros Mexicanos,", Diario oficial de la Federación Mexicana (MéxiCO, D. F.). 
Ferreira, Hector

1965 "Notas Sobre la Historia de la Pesquera Comercial de Camarón en el Pacifico de Mexico," Instituto Nacional de Investigaciones Biologico-Pesqueras 99 (Mexico, D. F.: Dirección General de Pesca e Industrias Conexas, Secretaría de Industria y Comercio).

Firth, Raymond A.

1965 Malay Fishermen: Their Peasant Economy, (London: Routledge and Kegan Paul).

Food and Agriculture Organization

1972 Trade Yearbook (Rome: Food and Agriculture Organization of the United Nations).

Fraser, Thomas M.

1966 Fishermen of South Thailand, (New York: Holt, Rinehart, and winston).

Gales, Lawrence E., James A. Buss, and L. J. Bledsoe

1977 "Simulation Concepts for Fishery Systems," Journal of the Fisheries Research Board of Canada 34 .

Gonzalez-Dávila, Amado

1959 Diccionario Geografico, Historico, Biografico, y Estadistico del Estado de Sinaloa, (Culiacán, Sinaloa).

Gulland, J.A.

1969 Manual of Methods for Fish Stock Assessment: Fish Population Amalysis, (Rome: Food and Agriculture Organization of the United Nations). 
Hubbs, Carl I., and Gunnar I. Roden

1964 "Oceanography and Marine Life Along the Pacific Coast of Middle America," In Robert C. West, vol. ed., The Handbook of Middle American Indians, Volume 1, (Austin: The University of Texas Press).

Kelly, J. Charles, and Howard D. Winters

1960 "A Revision of the Archaeological Sequence in Sinaloa, Mexico," American Antiquity 25, (December).

Koers, Albert $W$.

1973 International Regulation of Marine Fisheries, (London: Fishing News Books, Ltd.).

Lackey, Robert T.

1975 "Fisheries and Ecological Models in Fisheries Resource Management," In Clifford S. Russell, ed., Ecological Modeling in a Resource Management Framework, (Washington, D. C.: Resources for the Future, Inc.).

Lappé, Frances Moore, and Joseph Collins

1977 Food First: Beyond the Myth of Scarcity, (New York: Houghton Mifflin and Company).

Marine Fish Management (monthly newsletter)

Monthly, (Washington, D. C.: Nautilus Press, Inc.).

Mecham, J. Lloyd

1927 Francisco de Ibarra and Nueva Vizcaya, (Durham: University of North Carolina Press).

Mendoza von Borstel, Xavier

1972 "Efectos de la Marea Sobre la Producción Camaronera en Lagunas Litorales," Memorias de IV Congreso Nacional de Oceanografia, (Mexico, D. F.). 
Municipio de Escuinapa

1971 "Censo de Población y Vivienda levantados el día 8 de Enero," (Escuinapa, Sinaloa: Oficina del Presidente Municipal).

Murua Beltrân, Damaso

1968 "Nuevas Leyes, Orientación, y Financiamiento para la Pesca," Gaceta Cooperativa (December).

1970 "El Estado Mexicano como Promotor de la Pesca," Gaceta Cooperativa (July).

Nishimura, Asahitaro

1973 "A Preliminary Report on Current Trends in Marine Anthropology," Occasional Papers of the Center of Marine Ethnology 1, (Tokyo: Waseda University).

Norbeck, Edward

1954 Takashima: A Japanese Fishing Village, (Salt Lake City: The University of Utah Press).

Paz, Octavio

1972 The Other Mexico: Critique of the Pyramid, (New York: Grove Press).

Pi-Sunyer, Oriol

1973 Zamora: Change and Continuity in a Mexican Town, (New York: Holt, Rinehart, and Winston).

Rothschild, Brian J., ed.

1972 World Fishery Policy: Multidisciplinary Views, (Seattle: University of Washington Press).

Sauer, Carl, and Donald Brand

1932 "Aztatlán," Ibero Americana (monograph) 1. 
Schaaf, W. E.

1975 "Fish Population Models: Potential and Actual Links to Ecological Models,"In Clifford S. Russell, ed., Ecological Modeling in a Resource Management Framework, (Washington, D. C.: Resources for the Future, Inc.)

Scott, Stuart D., et al. (annual reconnaissance reports)

1967- Archeological Reconnaissances and Excavations

1972 in the Marismas Nacionales, Sinaloa and Nayarit, Mexico, (Buffalo: State University of New York at Buffalo).

Spicer, Edward $\mathrm{H}$.

1969 "Northwest Mexico," In Evon Z. Vogt, ed., Handbook of Middle American Indians, Volume 8, (Austin: The University of Texas Press).

Stavenhagen, Rodolfo

1970 "Social Aspects of Agrarian Structures in Mexico," In Rodolfo Stavenhagen, ed., Agrarian Problems and Peasant Movements in Latin America, (New York: Anchor Books).

Téchnica Pesquera (editors)

1972 "Ayúdate que Japón te Ayudará," and "Información Nacional," Téchnica Pesquera (March).

United Nations

1971 Economic Survey of Latin America, 2972, (New York: United Nations)

Wadsworth, Peter

1973 "The Limits of the Shrimp Fleet," Téchnica Pesquera 50 (March).

Wagner, Frederic H.

1969 "Ecosystem Concepts in Fish and Game Management," In George M. Van Dyne, ed., The Ecosystem Concept in Natural Resource Management, (New York: Academic Press). 
No. of Copies

3

1

5

25
Address

National Sea Grant Depository Pell Marine Science Library University of Rhode Island Kingston, RI 02881

Ms. Mary Holliman Sea Grant 70's Food Sclence Department V.P.I. and S.U.

Blacksburg, VA 24060

Office of Sea Grant 6010 Executive Boulevard Rockville, Maryland 20852 ATTN: Dr. Nalda Yolen

Mrs. E. Downs

Acquisitions Section, IRDB-D823 Lib. \& Info. Serv. Div., NOAA 6009 Executive Blvd.

Rockville, Md. 20852 


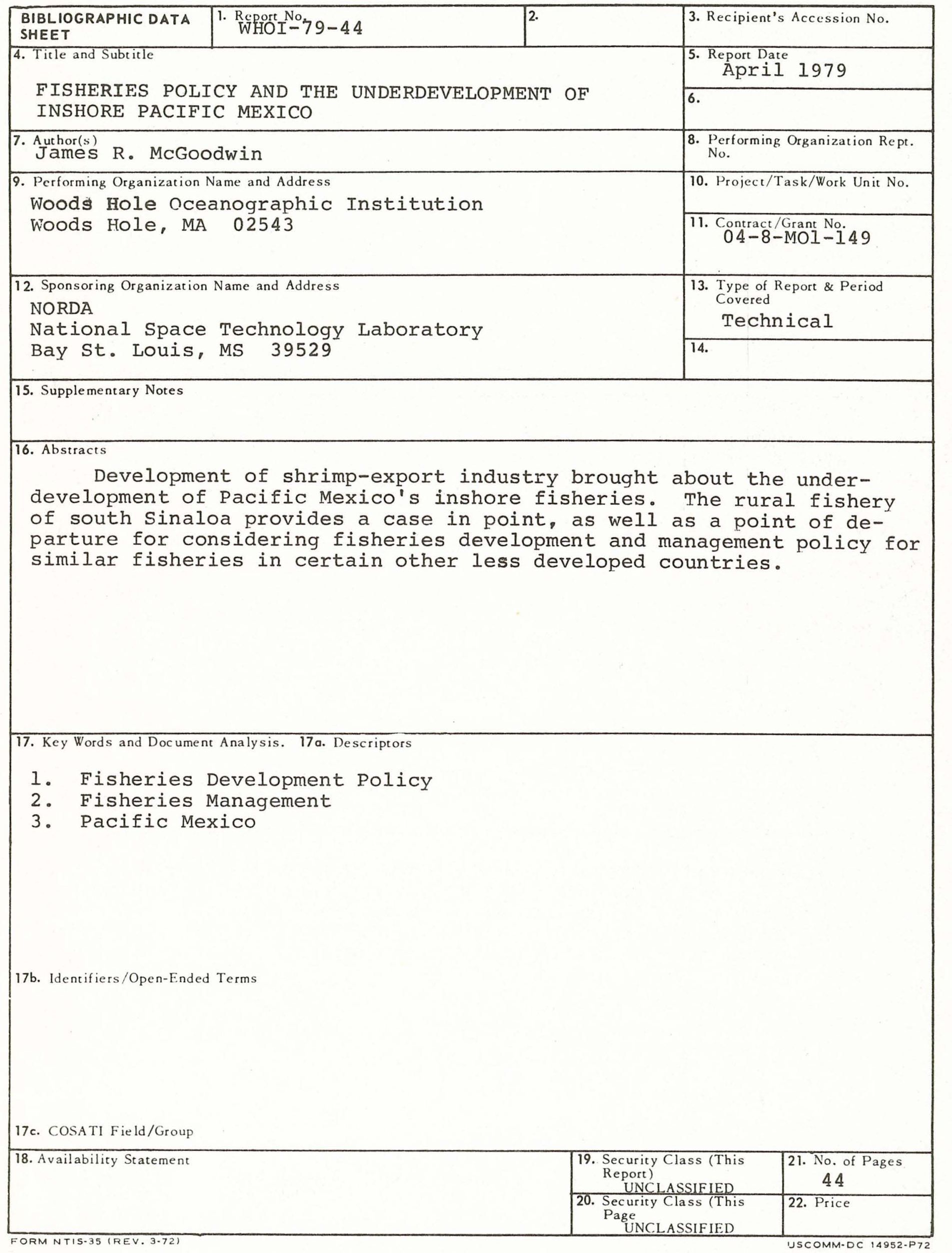




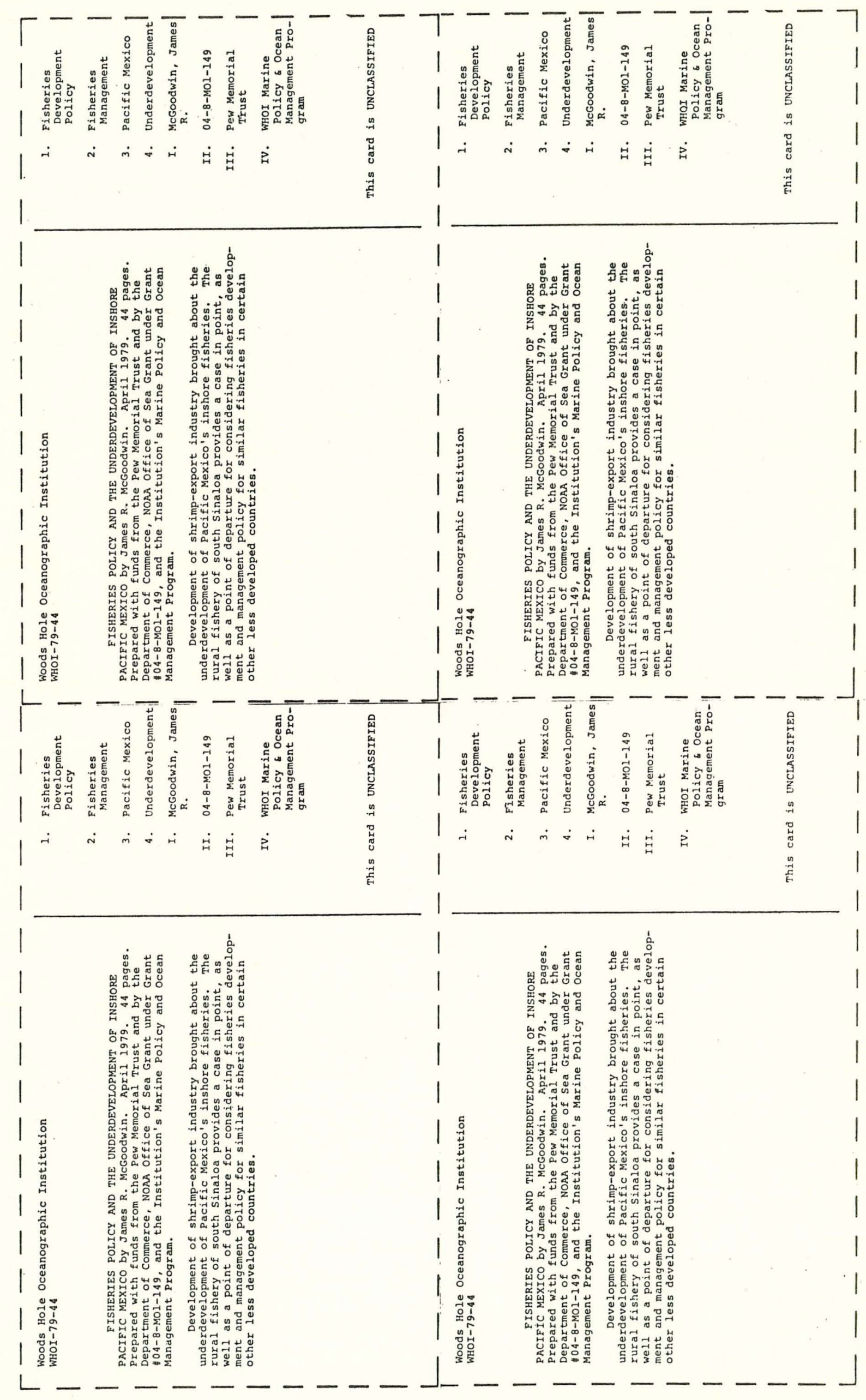

